\title{
Comparative genetic diversity studies of Theobroma cacao L. using RFLP and RAPD markers
}

\author{
J. A. K. N'GORAN, V. LAURENT, A. M. RISTERUCCI \& C. LANAUD \\ Laboratoire Biotrop/CIRAD (Centre de Coopération Internationale en Recherches Agronomiques pour le \\ Développement), BP 5035, 34032 Montpellier cedex, France
}

\begin{abstract}
The genetic diversity of 106 genotypes of Theobroma cacao L. was assessed using RFLP and RAPD methods. Thirty-one cDNA probes and 19 primers generated, respectively, 87 and 49 polymorphic bands that were submitted to factorial and cluster analyses. Both RFLP and RAPD bands separated the individuals into three distinctive groups. Some genotypes did not correspond to the currently accepted classification and are considered to have been originally misclassified. The nature of RAPD bands was investigated by Southern analysis. There were as many highly repeated sequences as single copy sequences but the two types of sequences did not structure the variability in the same way. Similar results were obtained with RFLPs and RAPDs with regard to the genetic structure of Theobroma cacao L. Therefore, RAPDs appear to be as efficient as RFLPs for classifying cocoa genotypes.
\end{abstract}

Keywords: genetic diversity, RAPD, RFLP, Theobroma cacao L.

\section{Introduction}

Based on morphological characteristics and geographical distribution, Theobroma cacao $\mathrm{L}$. has been subdivided into three main groups, namely Forastero, Criollo and Trinitario. Forastero clones originated in the Amazonian region of South America and possess green pods with predominantly purple seeds. Most cultivated clones are Forastero which represent over 80 per cent of the world cocoa production. Forastero have been further subdivided into Upper Amazon and Lower Amazon because of their geographical locations and some distinctive characteristics (e.g. precocity and disease resistance). Criollo were the first domesticated cocoas and originated in Central America and in the north of South America. They possess large white or rosy beans that give a desirable chocolate although they have poor agronomic value. Trinitario are hybrids between Criollo and Forastero. The great variability of pods and seeds makes it difficult to distinguish cocoa groups. Moreover, lack of information on a large number of clones limits their use in breeding programmes.

\footnotetext{
${ }^{*}$ Correspondence.
}

Although morphological characters have allowed Engels (1986) to discriminate Criollo from Forastero within a pool of 294 genotypes, these characters are affected by environmental effects and are difficult to measure because of their continuous variation. Lanaud (1987) used six enzymatic systems representing nine loci to assess the genetic diversity of 350 genotypes of cocoa. She uncovered great variability among Forastero clones as was encountered by Pound (1945) during his collecting trips in the Upper Amazon region, but the small number of enzymatic markers available did not allow the fine discrimination of groups as described by Cheesman (1944). The availability of new, abundant and neutral genetic markers has allowed some progress in the discrimination of groups. Laurent et al. (1993a, 1993b, 1994) used three types of RFLP probes to assess the genetic diversity of 203 genotypes. Ribosomal nuclear DNA probes distinguished Criollo, American Trinitario and Forastero. Mitochondrial probes revealed considerable variability among Criollo clones and cDNA probes confirmed the original structuring into Forastero and Criollo. However, the RFLP technique is labour intensive and the use of radioelements makes it difficult to extend its use to developing countries. RAPDs on the other hand are easier to 
develop and handle (Williams et al., 1990) and have proved to be valuable for a number of purposes. They have been used for establishing genetic linkage maps (Carlson et al., 1991; Fauré et al., 1993), for fingerprinting (Fukuoka et al., 1992; Wilde et al., 1992) and for diversity studies (Kazan et al., 1993; Stiles et al., 1993). Although RAPDs are simple, their results are sometimes controversial because of a lack of repeatability of some amplification products. In this study, we compare the structure of the genetic variability obtained by RAPD and RFLP methods, to test the general reliability of RAPD techniques in cocoa in order to apply it for cocoa germplasm characterization as a possible alternative to RFLPs.

\section{Materials and methods}

\section{Plant material}

A total of 101 genotypes of Theobroma cacao belonging to various groups and origins were collected from different research stations as dried leaves and used for RFLP studies (Table 1). One hundred and six acces-

Table 1 List of clones used for RAPD and cDNA analyses

\begin{tabular}{lll}
\hline Origin & Clone name & Source \\
\hline
\end{tabular}

\section{a. Trinitario clones}

Trinidad

Venezuela

Côte d'Ivoire

Ghana

Indonesia

Samoa

Java

Ecuador

$\begin{array}{ll} & \text { EQX107 } \\ & \text { MOQ413 } \\ \text { Honduras } & \text { MT1 } \\ & \text { TJ1 } \\ \text { Nigeria } & \text { N38 } \\ \text { Mexico } & \text { RIM15 } \\ \text { Colombia } & \text { SC5 } \\ & \text { SPEC160-9 } \\ \text { Costa Rica } & \text { CC39 } \\ & \text { UF221 }\end{array}$

$\begin{array}{lll}\text { ACT2-11 } & 1 & \text { Peru } \\ \text { ICS16 } & 1 & \text { Colombia }\end{array}$

Table 1 Continued

\begin{tabular}{|c|c|c|}
\hline Origin & Clone name & Sour \\
\hline \multicolumn{3}{|l|}{ b. Criollo clones } \\
\hline Venezuela & CATA201 & 4 \\
\hline \multirow[t]{18}{*}{ Venezuela } & CHUAO24 & 4 \\
\hline & CHO31 & 4 \\
\hline & CHUAO49 & 4 \\
\hline & CHUAO211 & 4 \\
\hline & CUM214 & 4 \\
\hline & Hernandez 212 & 4 \\
\hline & JS206 & 4 \\
\hline & OC61 & 1 \\
\hline & OC73 & 4 \\
\hline & OC77 & 4 \\
\hline & POC & 1 \\
\hline & POR & 1 \\
\hline & Porcelana Rojo & 4 \\
\hline & Providencia201 & 4 \\
\hline & PV2 & 3 \\
\hline & PV6 & 3 \\
\hline & ZEA1 & 4 \\
\hline & ZEA206 & 4 \\
\hline \multirow[t]{3}{*}{ Nicaragua } & ICS39 & 1 \\
\hline & ICS60 & 1 \\
\hline & ICS100 & 1 \\
\hline Mexico & La Esmida & 3 \\
\hline Indonesia & G8 & 1 \\
\hline \multirow[t]{2}{*}{ Costa Rica } & LAF1 & 3 \\
\hline & $\mathrm{LAF3}^{2}$ & 3 \\
\hline Peru & PA35 & 1 \\
\hline Colombia & SPEC $185-4^{3}$ & 1 \\
\hline \multicolumn{3}{|c|}{ c. Lower Amazon Forastero clones } \\
\hline \multirow[t]{12}{*}{ Brazil } & Comun tipico & 3 \\
\hline & ERJOH ${ }^{\mathrm{m}}$ & 2 \\
\hline & $\mathrm{ERJOH}_{4}^{\mathrm{j}}$ & 2 \\
\hline & ERJOH5 & 2 \\
\hline & ERJOH6 ${ }^{k}$ & 2 \\
\hline & ERJOH9 & 2 \\
\hline & ERJOH10 & 2 \\
\hline & ERJOH15 & 2 \\
\hline & IFC361 & 1 \\
\hline & Para & 3 \\
\hline & SIAL70 & 3 \\
\hline & SIC 864 & 1 \\
\hline \multirow[t]{2}{*}{ Fr. Guyana } & GU144 ${ }^{f}$ & 1 \\
\hline & GU349" & 1 \\
\hline \multirow[t]{3}{*}{ Ecuador } & $\mathrm{ECNR}^{\mathrm{h}}$ & 5 \\
\hline & EET59 & 2 \\
\hline & Nacional $^{n}$ & 3 \\
\hline \multirow[t]{6}{*}{ Côte d'Ivoire } & IFC1 & 1 \\
\hline & IFC2 & 1 \\
\hline & $\mathrm{IFC}^{7}{ }^{7}$ & 1 \\
\hline & IFC5 & 1 \\
\hline & IFC15 & 1 \\
\hline & SF23 ${ }^{\mathrm{d}}$ & 1 \\
\hline Ghana & IFC 307 & 1 \\
\hline
\end{tabular}


Table 1 Continued

\begin{tabular}{|c|c|c|}
\hline Origin & Clone name & Source \\
\hline Costa Rica & MAT1-6 & 1 \\
\hline Venezuela & VENC4 & 1 \\
\hline \multicolumn{3}{|c|}{ d. Upper Amazon Forastero clones } \\
\hline Peru & Amazon 15-15 & 1 \\
\hline \multirow[t]{3}{*}{ Colombia } & $\mathrm{EBC} 10$ & 1 \\
\hline & SPA5 ${ }^{\mathrm{i}}$ & 3 \\
\hline & $\operatorname{SPA} 17^{6}$ & 3 \\
\hline \multirow[t]{10}{*}{ Ecuador } & IMC67 & 1 \\
\hline & IMC31 & 1 \\
\hline & LCTEEN37 & 1 \\
\hline & LCTEEN84 & 5 \\
\hline & LCTEEN127 & 5 \\
\hline & LCTEEN325 & 5 \\
\hline & LCTEEN371 & 1 \\
\hline & SCA6 ${ }^{a}$ & 1 \\
\hline & $\mathrm{SCA}^{\mathrm{b}}$ & 1 \\
\hline & $\mathrm{SCA} 12^{\mathrm{c}}$ & 1 \\
\hline \multirow[t]{6}{*}{ Peru } & PA13 & 1 \\
\hline & PA150 & 1 \\
\hline & $\mathrm{P} 2^{4}$ & 1 \\
\hline & P32 $\mathrm{A}^{5}$ & 1 \\
\hline & MO81 & 1 \\
\hline & NA32 & 1 \\
\hline \multirow[t]{3}{*}{ Ghana } & T60/887 & 1 \\
\hline & T63/967 & 1 \\
\hline & $\mathrm{T} 85 / 799$ & 1 \\
\hline \multirow[t]{2}{*}{ Côte d'Ivoire } & UPA413 & 1 \\
\hline & UPA603 & 1 \\
\hline
\end{tabular}

Letters or numbers above the names of clones refer to the position of clones on the first plane of factorial analyses of Fig. 1 and Fig. 2. Clones in bold were used only for RAPD. Dried leaves were received from IDEFOR/DCC(1), CEPEC(2), CATIE(3), CENIAP(4) and CRU(5).

sions (Table 1) were used for RAPD analyses (101 were common to both studies).

\section{cDNA isolation}

cDNA probes were synthesized from fresh seed tissue using Pharmacia kits. They were ligated into pUC18 and used to transform strain DH5 $\alpha$ of E. coli. Plasmids were isolated by minipreparation and inserts were amplified by PCR and extracted from low-melting agarose gels.

\section{Total DNA extraction and RFLP procedures}

Total DNA was extracted from dried leaves as described by Laurent et al. (1993a, b). Five micro- grams of total DNA were digested with four restriction enzymes (EcoRI, XbaI, EcoRV, HindIII) and transferred to a nylon membrane (Hybond $\mathrm{N}^{+}$). Thirty-one cDNA probes were labelled by random priming with ${ }^{32} \mathrm{PdCTP}$ and used to probe blots containing digested total DNA. Prehybridizations and hybridizations were performed overnight at $42^{\circ} \mathrm{C}$ in a solution containing 50 per cent formamide $6 \times \mathrm{SSC}, 5 \times$ Denhart, 0.5 per cent SDS and $25 \mu \mathrm{g} / \mathrm{mL}$ herring sperm DNA. Autoradiographs were exposed at $-80^{\circ} \mathrm{C}$ for a week.

\section{RAPD procedures}

Each amplification was performed in a reaction volume of $25 \mu \mathrm{L}$ containing $1 \times$ Promega reaction buffer, $0.2 \mu \mathrm{M}$ of primer, $1.5 \mathrm{~mm} \mathrm{MgCl}_{2}, 200 \mu \mathrm{M}$ of each of the dNTPs, $5 \mathrm{ng}$ of total DNA and 1.5 units of Taq polymerase (Promega). Primers from Operon Technologies (Kits D, K, L, M, P, Q) previously screened in a mapping project were used. Amplifications were carried out in a Techne PHC 2 thermocycler. After an initial denaturation step at $94^{\circ} \mathrm{C}$ for $5 \mathrm{~min}, 43$ cycles of $1 \mathrm{~min}$ at $93^{\circ} \mathrm{C}, 50 \mathrm{~s}$ at $36^{\circ} \mathrm{C}$ and $2 \mathrm{~min}$ at $72^{\circ} \mathrm{C}$ were performed followed by a final incubation phase of $10 \mathrm{~min}$ at $72^{\circ} \mathrm{C}$. Amplification products were then analysed by electrophoresis in 1.4 per cent agarose gels run at $100 \mathrm{~V}$ for $3-4 \mathrm{~h}$ in a TBE buffer and stained with ethidium bromide. Repeatability tests and primer screening were conducted on a sample of 19 genotypes belonging to different origins. Nineteen primers generated 49 stable and readable bands that were scored for their presence or absence.

The nature of 39 polymorphic RAPD products was investigated by Southern analysis. Amplification product leftovers were allowed to migrate overnight in 1.2 per cent low-melting agarose gels. They were extracted from the gels and hybridized to blots containing total DNA of five clones digested with five restriction enzymes ( $B g I l \mathrm{I}, E c o$ RI, $X b a \mathrm{I}, E c o$ RV, HindIII) as described in the RFLP procedures.

\section{Statistical analyses}

RAPD or RFLP data were scored as presence or absence of bands in each genotype. A $\chi^{2}$ test was used to compare the frequencies of RAPD bands in populations. Data were then subjected to factorial analyses of correspondences (FAC) (Benzécri, 1973). Cluster analyses were performed on the coordinates of factorial axes and phenograms were built by the average method (UPGMA). After investigation of RAPD bands, single copy and highly repeated sequences were analysed separately. All statistical analyses were performed using ADDAD software (Addad, 1985). 


\section{Results}

\section{cDNA analysis}

Thirty-one cDNA probes produced 87 polymorphic fragments that were scored for their presence or absence in the genotypes.

The first plane of the factorial analysis (Fig. 1) represents 31.2 per cent of the total variability. It distinguishes Upper Amazon Forastero, Criollo and Lower Amazon Forastero. Forastero clones exhibit a wider range of variability compared with Criollo clones. Trinitario clones cluster either with Criollo or with Lower Amazon Forastero. In the Forastero group, the Scavina genotypes (a, b, c) known as good parents in crosses lie outside the pool of Upper Amazon clones. Wild French Guyana clones (e, f), some Ecuadorian clones $(\mathrm{h}, \mathrm{l})$ and some genotypes from Brazil $(\mathrm{g}, \mathrm{k}, \mathrm{m})$ are not included within the Lower Amazon Forastero group. Criollo genotypes, except some $(1,2,3)$ are concentrated in the lower right quarter of the plane.

A phenogram based on coordinates of factorial analysis identified Upper Amazon Forastero, lower Amazon Forastero and Criollo (data not shown). Trinitario clustered either with Lower Amazon Forastero or
Criollo clones and a small cluster comprises the Upper Amazon Scavina genotypes.

\section{RAPD analysis}

Nature of RAPD products in cocoa. Southern analysis of RAPD products revealed three types of patterns: 12 amplification products used as probes gave one to three bands on blots and were therefore considered as single copy sequences, 12 other products generated a smear on blots and were identified as highly repeated dispersed sequences and a third type of product induced more than three discrete bands with or without background smears. This last type could not be unambiguously assigned. Some amplification products could not be extracted alone from gels whatever the duration of migration because they were too close to other bands.

Level of polymorphism and comparison of RAPD products in populations. The 19 primers generated one to five polymorphic fragments. The size of bands ranges from 0.3 to $2 \mathrm{~kb}$. Some bands occur more often in some populations. A $\chi^{2}$ test was performed on the data for uniformity of band presence in the populations

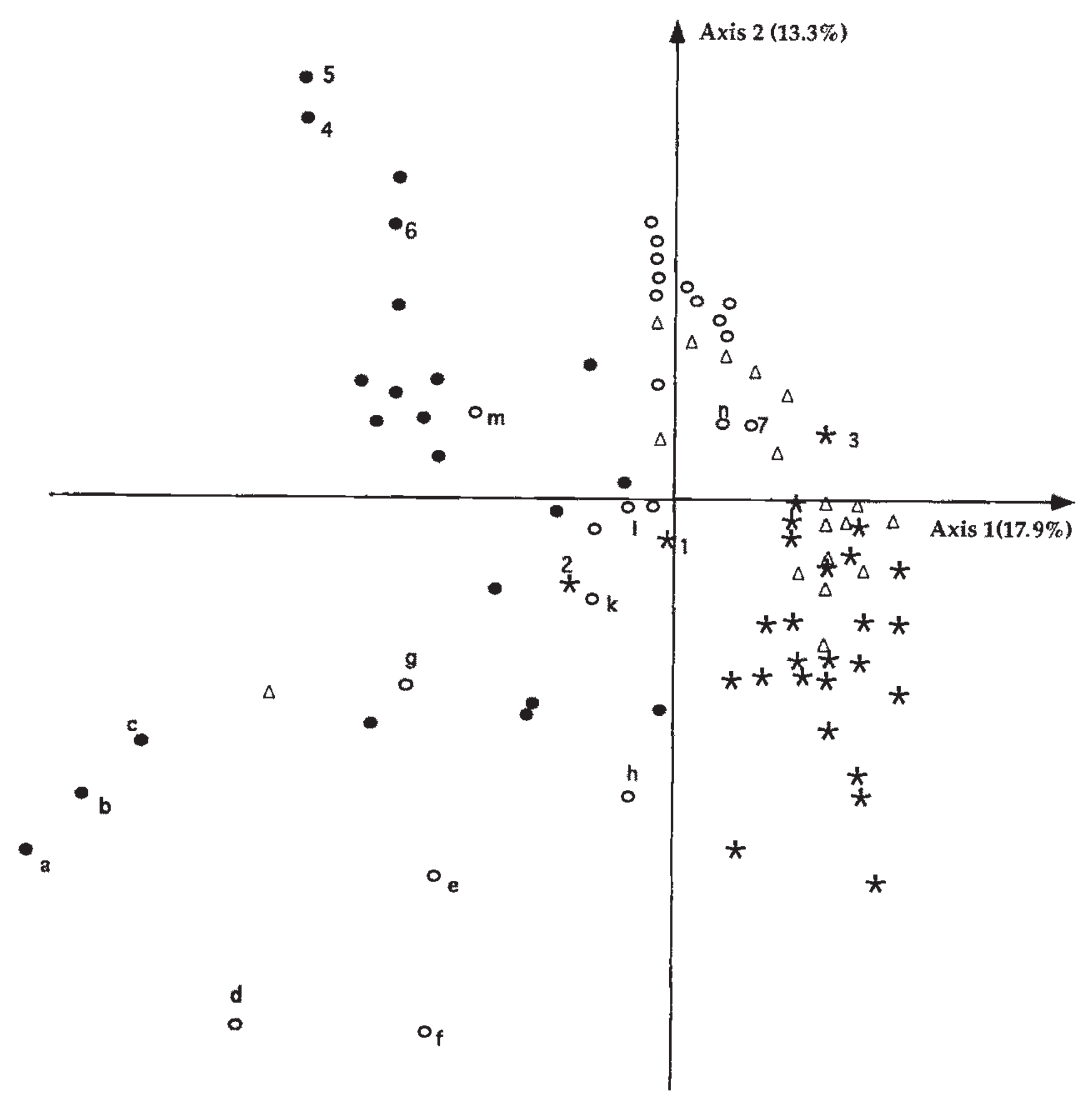

Fig. 1 Plane 1 (31.2 per cent of variability) of factorial analysis of correspondences on cDNA data. The first axis discriminates Upper Amazon Forastero from Criollo. See Table 1 for letters and numbers. (*) Criollo; $(\bullet)$ Upper Amazon Forastero; $(0)$ Lower Amazon Forastero; $(\Delta)$ Trinitario. 
Table 2 Frequencies of RAPD fragments in populations

\begin{tabular}{|c|c|c|c|c|c|c|c|c|c|c|c|}
\hline \multirow{2}{*}{$\begin{array}{l}\text { RAPD } \\
\text { fragment }\end{array}$} & \multirow[b]{2}{*}{ Nature } & \multicolumn{4}{|c|}{$\begin{array}{l}\text { Percentage of presence } \\
\text { in populations }\end{array}$} & \multicolumn{6}{|c|}{$\begin{array}{l}\text { Level of significance for pairwise comparison between } \\
\text { populations }\end{array}$} \\
\hline & & LA & $\mathrm{C}$ & UA & $\mathrm{T}$ & LA-C & LA-UA & LA-T & C-UA & $\mathrm{C}-\mathrm{T}$ & UA-T \\
\hline rOPD15/0.5 & - & 8 & 19 & 40 & 4 & NS & $* *$ & NS & NS & NS & $* *$ \\
\hline rOPD15/1.0 & - & 24 & 38 & 76 & 46 & NS & $* *$ & NS & $* *$ & NS & $*$ \\
\hline rOPD15/1.2 & $\mathrm{S}$ & 84 & 92 & 88 & 74 & NS & NS & NS & NS & NS & NS \\
\hline rOPD15/1.4 & - & 72 & 73 & 68 & 70 & NS & NS & NS & NS & NS & NS \\
\hline rOPD15/1.8 & $\mathrm{S}$ & 16 & 92 & 36 & 67 & $* *$ & NS & $* *$ & $* *$ & $*$ & $*$ \\
\hline rOPK $07 / 0.3$ & $\mathrm{~S}$ & 27 & 41 & 42 & 61 & NS & NS & $* *$ & NS & NS & NS \\
\hline rOPK07/0.5 & $\mathrm{R}$ & 8 & 78 & 38 & 64 & $* *$ & $*$ & $* *$ & $* *$ & NS & NS \\
\hline rOPK08/0.3 & $\mathrm{S}$ & 17 & 60 & 29 & 46 & $* *$ & NS & NS & $*$ & NS & NS \\
\hline rOPK08/1.5 & - & 21 & 13 & 29 & 15 & NS & NS & NS & NS & NS & NS \\
\hline rOPK09/0.6 & LR & 100 & 84 & 84 & 93 & $*$ & $*$ & NS & NS & NS & NS \\
\hline rOPK09/1.3 & LR & 36 & 32 & 40 & 52 & NS & NS & NS & NS & NS & NS \\
\hline rOPK13/0.4 & $\mathrm{R}$ & 85 & 69 & 75 & 74 & NS & NS & NS & NS & NS & NS \\
\hline rOPK13/1.5 & $\mathrm{R}$ & 31 & 77 & 33 & 67 & $* *$ & NS & $*$ & $* *$ & NS & $*$ \\
\hline rOPK15/0.9 & LR & 35 & 78 & 71 & 29 & $* *$ & $*$ & NS & NS & $* *$ & $* *$ \\
\hline rOPK15/1.4 & $\mathrm{U}$ & 23 & 74 & 71 & 14 & $* *$ & $* *$ & NS & NS & $* *$ & $* *$ \\
\hline rOPL02/0.3 & $S$ & 83 & 39 & 33 & 92 & $* *$ & $* *$ & NS & NS & $* *$ & $* *$ \\
\hline rOPL02/1.0 & $\mathrm{R}$ & 15 & 35 & 25 & 24 & NS & NS & NS & NS & NS & NS \\
\hline rOPL02/1.4 & $S$ & 65 & 96 & 92 & 64 & $* *$ & $* *$ & NS & NS & $* *$ & $* *$ \\
\hline rOPL05/0.7 & - & 35 & 4 & 68 & 18 & $* *$ & $*$ & NS & $* *$ & NS & $* *$ \\
\hline rOPL05/0.9 & $\mathrm{S}$ & 15 & 0 & 20 & 7 & $*$ & NS & NS & $*$ & NS & NS \\
\hline rOPL11/0.6 & $\mathbf{R}$ & 28 & 88 & 22 & 60 & $* *$ & NS & $*$ & $* *$ & $*$ & $*$ \\
\hline rOPL11/0.8 & $\mathrm{R}$ & 16 & 88 & 22 & 56 & $* *$ & NS & $* *$ & $* *$ & $* *$ & $*$ \\
\hline rOPL11/0.9 & - & 76 & 56 & 78 & 65 & NS & NS & NS & NS & NS & NS \\
\hline rOPL19/0.4 & LR & 48 & 96 & 82 & 74 & $* *$ & $*$ & NS & NS & $*$ & NS \\
\hline rOPL19/0.5 & $\mathrm{S}$ & 28 & 50 & 68 & 48 & NS & $* *$ & NS & NS & NS & NS \\
\hline rOPL19/0.8 & $\mathrm{U}$ & 88 & 96 & 83 & 81 & NS & NS & NS & NS & NS & NS \\
\hline rOPM17/0.6 & $\mathrm{S}$ & 81 & 65 & 56 & 82 & NS & NS & NS & NS & NS & $*$ \\
\hline rOPM17/1.1 & $\mathrm{S}$ & 81 & 62 & 80 & 32 & NS & NS & $* *$ & NS & NS & ** \\
\hline rOPM17/2.1 & $\mathrm{U}$ & 73 & 85 & 84 & 61 & NS & NS & NS & NS & $*$ & $*$ \\
\hline rOPM20/0.5 & LR & 64 & 96 & 87 & 88 & $* *$ & NS & $*$ & NS & NS & NS \\
\hline rOPM20/0.6 & LR & 12 & 74 & 13 & 33 & $* *$ & NS & NS & $* *$ & $* *$ & NS \\
\hline rOPM20/1.8 & LR & 80 & 96 & 78 & 58 & NS & NS & NS & NS & $* *$ & NS \\
\hline $\mathrm{rOPO} 04 / 0.9$ & - & 38 & 57 & 45 & 70 & NS & NS & $*$ & NS & NS & NS \\
\hline rOPO04/1.0 & - & 75 & 57 & 95 & 80 & NS & NS & NS & $* *$ & NS & NS \\
\hline $\mathrm{rOPO} 04 / 1.4$ & - & 83 & 86 & 85 & 70 & NS & NS & NS & NS & NS & NS \\
\hline rOPO13/0.8 & LR & 40 & 55 & 58 & 54 & NS & NS & NS & NS & NS & NS \\
\hline rOPO13/0.9 & $\mathbf{R}$ & 86 & 91 & 88 & 96 & NS & NS & NS & NS & NS & NS \\
\hline rOPO13/1.4 & $\mathrm{S}$ & 82 & 64 & 42 & 92 & NS & ** & NS & NS & $*$ & $* *$ \\
\hline rOPO15/0.5 & LR & 15 & 96 & 67 & 57 & $* *$ & $* *$ & *** & $* *$ & $* *$ & NS \\
\hline rOPO15/0.6 & $\mathrm{S}$ & 19 & 26 & 25 & 50 & NS & NS & $*$ & NS & $*$ & $*$ \\
\hline rOPO15/2.0 & LR & 15 & 24 & 4 & 39 & NS & NS & NS & $*$ & NS & $* *$ \\
\hline rOPP03/0.8 & - & 48 & 23 & 58 & 14 & $*$ & NS & $* *$ & $* *$ & NS & $* *$ \\
\hline rOPP03/1.5 & $\mathrm{U}$ & 77 & 4 & 8 & 54 & $* *$ & $* *$ & * & NS & $* *$ & $* *$ \\
\hline rOPP14/0.4 & $\mathrm{R}$ & 19 & 92 & 17 & 59 & $* *$ & NS & $* *$ & $* *$ & $* *$ & $* *$ \\
\hline rOPP14/0.6 & $\mathbf{R}$ & 27 & 92 & 35 & 52 & $* *$ & NS & NS & $* *$ & $* *$ & NS \\
\hline rOPP14/0.9 & $\mathrm{R}$ & 23 & 29 & 30 & 41 & NS & NS & NS & NS & NS & NS \\
\hline rOPP16/0.6 & $\mathrm{R}$ & 42 & 89 & 76 & 82 & $* *$ & $*$ & $* *$ & NS & NS & NS \\
\hline $\mathrm{rOPQ} 15 / 0.3$ & U & 84 & 77 & 67 & 89 & NS & NS & NS & NS & NS & NS \\
\hline rOPQ $15 / 0.5$ & $\mathrm{R}$ & 56 & 54 & 46 & 52 & NS & NS & NS & NS & NS & NS \\
\hline
\end{tabular}

Differences between populations are nonsignificant (NS), significant at the $5 \%$ level $\left({ }^{*}\right)$ or significant at the $1 \%$ level $\left({ }^{* *}\right)$. RAPD fragments are designated by the primer that generated them and their size (for example rOPK 15/0.9; r for RAPD, OP for Operon, $\mathrm{K} 15$ is the name of the primer, $0.9 \mathrm{~kb}$ is the size).

UA: Upper Amazon Forastero; LA: Lower Amazon Forastero; T: Trinitario; C: Criollo. RAPD bands are repeated sequences $(\mathrm{R})$, single copy sequences $(\mathrm{S})$, low repeats $(\mathrm{LR})$, unassigned $(\mathrm{U})$ or could not be extracted $(-)$. 
(Table 2). Significant differences in frequencies were revealed for some bands although no populationspecific band was obtained. A pairwise comparison of frequencies in populations revealed that Lower Amazon Forastero clones are close to Upper Amazon Forastero and to Trinitario. Trinitario are also related to Criollo as was expected from current classification.

\section{Diversity organization}

Bulk polymorphic RAPD products analysis. The first plane of the FAC using all polymorphic bands without any distinction of their nature represents 24.3 per cent of the total variability (Fig. 2). The first axis discriminates Forastero into Upper Amazon and Lower Amazon, while the second axis distinguishes Forastero from Criollo. Trinitario clones are spread between Lower Amazon Forastero and Criollo. Most American Trinitario, probably with a strong Criollo background, cluster with Criollo and African Trinitario are characterized by a median position between Criollo and Lower Amazon Forastero. Some Ecuadorian clones $(\mathrm{h}$, n, 1), Guyana populations (e) and some Brazilian clones $(\mathrm{g}, \mathrm{k})$, usually classified as Lower Amazon Forastero, cluster however with Upper Amazon Forastero. Some Forastero genotypes $(5,6,7, \mathrm{~m})$ are characterized by a median position between Criollo and Forastero. Upper Amazon Scavina clones $(\mathrm{a}, \mathrm{b}, \mathrm{c})$ are well integrated within their group while the clone P2 (4) is included in the Lower Amazon Forastero group. Forastero and Trinitario show a wider range of variability than Criollo. Cluster analysis as well as FAC distinguishes Upper Amazon Forastero, Lower Amazon Forastero and Criollo but did not identify most Trinitario as a separate group. With the cluster analysis, Trinitario clones group together either with Criollo or with Lower Amazon Forastero (data not shown).

Analysis of single copy and repeated sequences derived from RAPD products. The first plane of the FAC on the 12 single copy RAPD bands represents 33 per cent of the variability. Forastero and Criollo could not be identified as separate groups (data not shown). Repeated sequences, on the other hand, structured the diversity better. The first plane, which accounts for 38.6 per cent of the total variability (Fig. 3) distinguishes clearly Criollo and Forastero. No discrimination could be made, however, between Upper and Lower Amazon Forastero clones. Trinitario are mixed up either with Forastero or with Criollo.

\section{Discussion and conclusion}

RAPD fragments are DNA sequences amplified by a polymerase. They could cover the entire genome by revealing coding or noncoding regions, repeated or

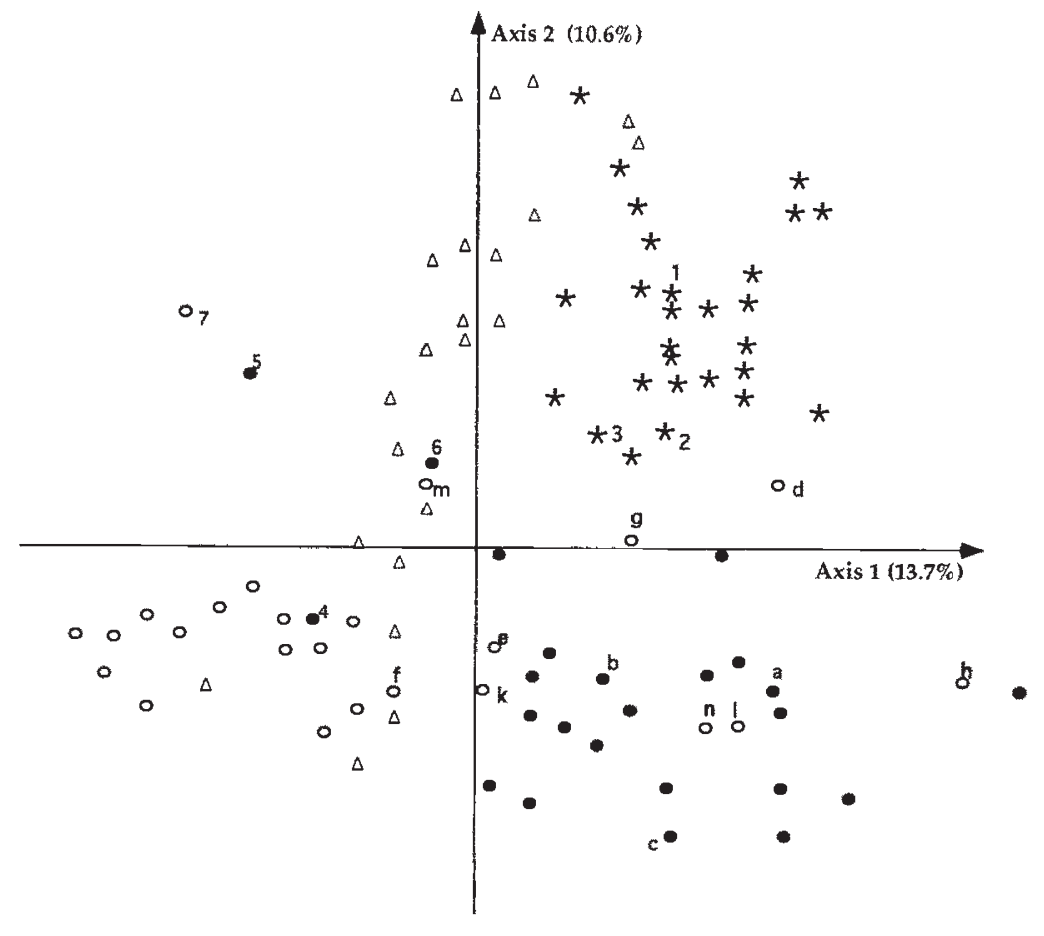

Fig. 2 Plane 1 (24.3 per cent of variability) of FAC based on RAPD data. Axis 1 separates Criollo and Upper Amazon Forastero from Lower Amazon Forastero whereas the second axis discriminates the two major groups Criollo and Forastero. See Table 1 for letters and numbers. (*) Criollo; $(\bullet)$ Upper Amazon Forastero; (0) Lower Amazon Forastero; $(\Delta)$ Trinitario. 
Fig. 3 Plane 1 ( 38.6 per cent of total variability) of FAC based on amplified repeated sequences discriminate the two major groups that are Criollo and Forastero. (*) Criollo; $(\bullet)$ Upper Amazon Forastero; $(0)$ Lower Amazon Forastero; $(\Delta)$ Trinitario.

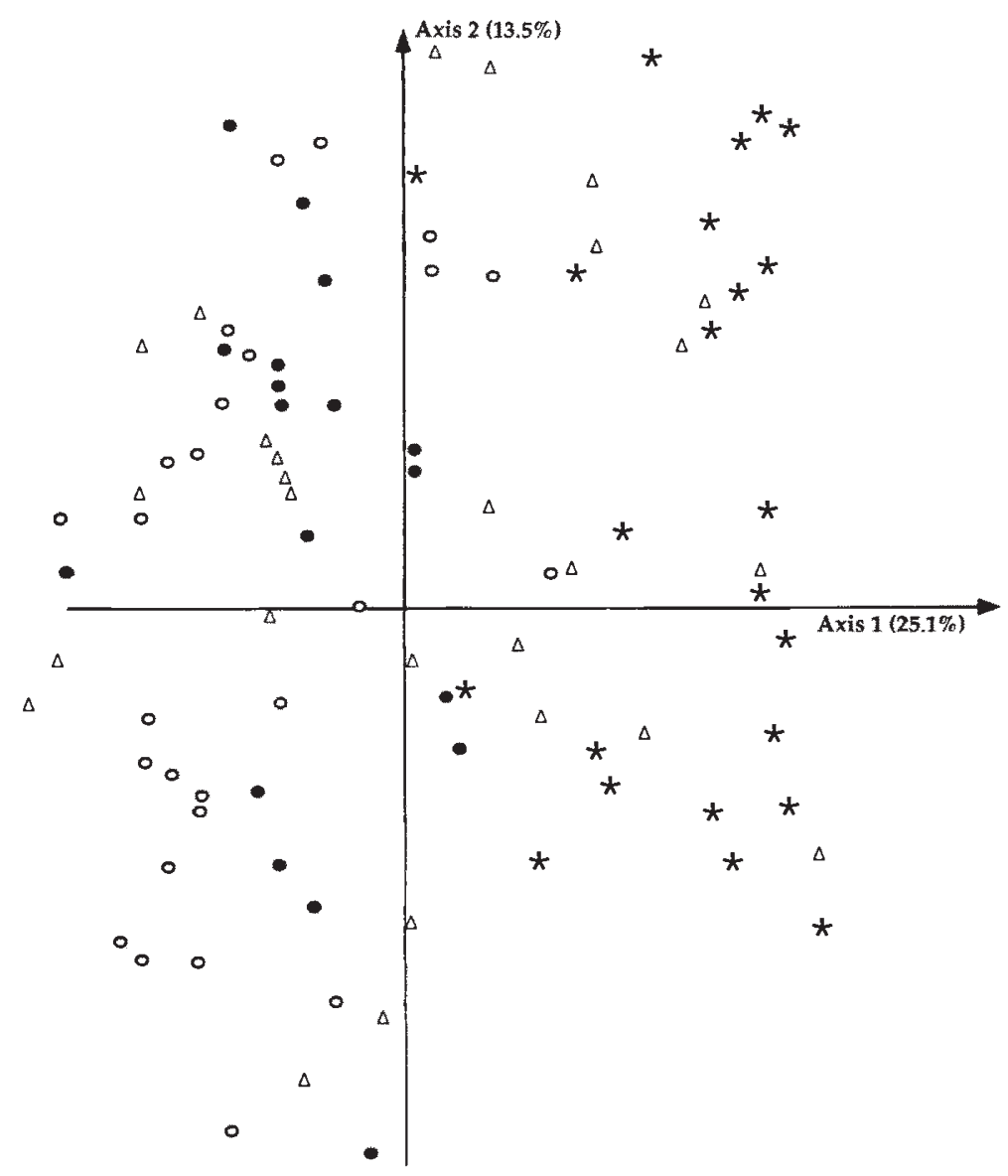

single copy sequences. The number of repeated sequences is correlated with the size of the genome (Vedel \& Delseny, 1987; Lapitan, 1992), and Lanaud et al. (1992) and Figueira et al. (1992) showed that the cocoa tree has a small genome of $0.4 \mathrm{pg}$ per haploid cell. One could, therefore, reasonably expect a relatively low percentage of repeated sequences in the cocoa genome. However, in the present study, more repeated sequences (high or low repeats) were found than single copy sequences. Repeated sequences may have been preferentially amplified by the RAPD technique. Repetitive and single copy sequences do not reflect the same evolutionary processes. According to Delseny et al. (1988), repetitive sequences could evolve more rapidly than single copy sequences by amplification and transposition. Amplified single copy probes were expected to structure the variability in the same way as cDNA sequences but, probably because of the number of sequences analysed, different features were observed. Amplified single copy sequence probes in this experiment gave similar results to enzymatic markers (Lanaud, 1987), revealing a wide range of variability among the Forastero group without any clear distinction between Forastero and Criollo. Amplified repeated sequence probes on the other hand gave the same results as morphological characters by separating Forastero from Criollo. Twelve repeated sequence probes were enough to discriminate the two major groups as did 39 morphological characters, cDNA and rDNA probes. Those repeated sequences seem to be well distributed over the genome and are different from rDNA which is a specific repeated sequence. In cocoa, the analyses of cDNA, rDNA, morphological characters and dispersed repeated RAPD sequences separated Criollo from Forastero and probably reflect ancient events that took place prior to the separation of Forastero into two subgroups. Forastero and Criollo genotypes might have first differentiated independently on each side of the Andean barrier as suggested by Cuatrecasas (1964). Later, mutational, transpositional and amplification events allowed a further genetic discrimination of Upper Amazon Forastero from Lower Amazon Forastero as shown in RFLP (Laurent et al., 1994) and by RAPD analyses. Trinitario clones have a 
hybrid origin, and are difficult to separate from Criollo or Lower Amazon clones most of the time. Only RAPD analysis has differentiated some of them.

RAPDs in cocoa seem to be a valuable tool to classify genotypes and are as useful as other complex methods of investigation. They have made it possible to gain access to several events in the domestication of Theobroma cacao, particularly recent events such as the creation of Trinitario. Figueira et al. (in press) and Lerceteau (1992) reported that they could not group genotypes according to the existing classification using RFLP and RAPD markers. The differences in the results may have arisen from the smaller size and the constitution of the population analysed.

Some genotypes are apparently misclassified by both types of molecular markers: ECNR(h), EET59(I) and SF23(d). This is not surprising for some Ecuadorian genotypes called 'Nacional'. Ecuador Nacional cocoa comprises genotypes with plump whitish beans usually classified as Lower Amazon clones (Soria, 1970) or Criollo clones (Enriquez, 1992). From these analyses based on two types of molecular markers, strong evidence exists that those clones are more related to Upper Amazon or Trinitario clones.

The cocoa clones from Brazil are shown by RAPD and RFLP/cDNA to be heterogeneous. Some show little variability and cluster with African Amelonado clones whose ancestors they are supposed to be. Others like Erjoh genotypes collected in the western part of Brazil are more diverse. Erjoh clones, on the plane of the factorial analysis spread in between Upper Amazon clones, to which they are close geographically, and Lower Amazon Forastero. Some types behave like Trinitario and are located in between Forastero and Criollo. The observed diversity within Brazilian wild germplasm is in accordance with the findings of Marcio et al. (1987) who collected plant material in the Rondonia area: those clones fit into a complex of diverse but genetically related clones.

Although a rather global agreement exists between RFLP and RAPD techniques for cocoa diversity studies, some particular results are obtained from each one. In the factorial analysis of cDNA data, Scavina genotypes are somewhat isolated from the other members of the Upper Amazon group whereas in the RAPD analysis they fit well in the group. P32A (5) and IFC4 (7) appear distinct on RAPD analysis, but are quite integrated in their usual respective group of classification in the cDNA analysis. These genotypes should be studied in more detail.

Based on these results, RAPD is an appropriate technique for studying the diversity of cocoa populations as RAPD analyses are fast and well suited for surveying large samples of genotypes such as those held in international gene banks.

\section{Acknowledgements}

We thank all Cocoa Research Stations for providing us with plant material. We are grateful to Dr B. G. D. Bartley and Dr G. Lockwood for information on the origins of clones.

\section{References}

ADDAD. 1985. Manuel de Référence. Association pour le Développement et la Diffusion de l'Analyse des données. Paris.

BENZECRI, J.P. (ED.) 1973. L'analyse des Données. Vol. 2. L'analyse des Correspondances. Dunod, Paris.

CARLSON, I. E, TULSIERAM, L. K., GLAUBitZ, J. C., LUK, V. W. K., KAUfFELDT, C. AND RUTLEDGE, R. 1991. Segregation of random amplified DNA markers in $F_{1}$ progeny of conifers. Theor. Appl. Genet., 83, 194-200.

CHEESMAN, E. E. 1944. Notes on the nomenclature, classification and possible relationships of cacao populations. Trop. Agric., 21, 144-159.

CUATRECASAS, J. 1964. Cacao and its allies: a taxonomic revision of the genus Theobroma. Bulletin of the United States National Museum, Smithsonian Institution (Washington), 35, 379-614.

DELSENY, M., GRELLET, F., TREMOUSAYGUE, D., RAYNAL, M. AND PANABIERES, F. 1988. Structure, évolution et expression de l'ADN nucléaire. Bull. Soc. bot. Fr., 135, Actual. bot. (2), 23-38.

EnGels, J. M. M. 1986. The Systematic Description of Cacao Clones and its Significance for Taxonomy and Plant Breeding. Ph.D. Thesis, Agricultural University of Wageningen.

ENRIQUEZ, G. A. 1992. Characteristics of cacao 'nacional' of Ecuador. International Workshop on Conservation, Characterisation and Utilisation of Cocoa Genetic Resources in the 21st Century. 13-17 September, Trinidad, pp. 269-278.

FAURE, S., NOYER, J. L., HORRY, J. P., BAKRY, F., LANAUD, C., GONZALEZ, D. AND LEON, D. 1993. A molecular markerbased linkage map of diploid bananas (Musa acuminata). Theor. Appl. Genet., 87, 517-526.

FIGUEIRA, A., JANICK, J. AND GOLDSBROUGH, P. 1992. Genome size and DNA polymorphism in Theobroma cacao. J. Am. Soc. Hort. Sci., 17, 673-677.

FIGUEIRA, A., JANICK, J., LEVY, M. AND GOLDSBROUGH, P.. Reexamining the classification of Theobroma cacao L. using molecular markers. XI International Cocoa Research Conference, 18-24 July 1993, Yamoussoukro, Côte d'Ivoire (in press).

FUKUOKA, S., HOSAK, K., KAMIJIMA, O. 1992. Use of random amplified polymorphic DNAs (RAPDs) for identification of rice accessions. Jap. J. Genet., 67, 243-252.

KAZAN, K., MANNERS, J. M. AND CAMERON, D. F. 1993. Genetic variation in agronomically important species of Stylosanthes determined using random amplified polymorphic DNA markers. Theor. Appl. Genet., 85, 882-888.

LANAUd, C. 1987. Nouvelles Données sur la Biologie du Cacaoyer (Theobroma cacao L.). Diversité des Populations, Système d'Incompatibilité, Haplö̈des Spontanés. 
Leurs Conséquences pour l'Amélioration Génétique de cette Espèce. Doctorat d'état, Université Paris XI.

LANAUD, C., HAMON, P., AND DUPERRAY, C. 1992. Estimation of the nuclear DNA content of Theobroma cacao L. by flow cytometry. Café, Cacao, Thé, 36, 3-8.

LAPITAN, N. L. v. 1992. Organization and evolution of higher plant nuclear genomes. Genome, 35, 171-181.

LAURENT, v., RISTERUCC, A. M. AND LANAUD, C. 1993a. Chloroplast and mitochondrial DNA diversity in Theobroma cacao. Theor. Appl. Genet., 87, 81-88.

LAURENT, V., RISTERUCCI, A. M. AND LANAUD, C. 1993b. Variability for nuclear ribosomal genes within Theobroma cacao. Heredity, 71, 96-103.

LAURENT, V., RISTERRUCCI, A. M. AND LANAUD, C. Genetic diversity in cocoa revealed by cDNA probes. Theor. Appl. Genet. (in press).

LERCETEAU, E. 1992. Evaluation de la diversité génétique de Theobroma cacao par les techniques de détection d'ADN polymorphe amplifié au hasard (RAPD) et de polymorphisme de longueur des fragments de restriction de l'ADN (RFLP). Rapport de stage du DEA de Biologie moléculaire et Cellulaire végétale. Université Paris XI.
MARCIO, C., DE ALMEIDA, V. C. AND GOMES DE ALMEIDA, C. F. 1987. Coleta de cacau silvestre no estado de Rondonia, Brasil. Rev. Theobromae, 17, 65-92.

POUND, F. J. 1945. A note on the cocoa populations of South America. Rep. Proc. Cocoa Conf., 131-133. London.

SORIA, J. v. 1970 . Principal varieties of cocoa cultivated in tropical America. Cocoa Growers' Bulletin, 19, 12-21.

STILES, J. 1., LEMME, C., SONDUR, S., MORSHIDI, M. B. AND MANSHARDT, R. 1993. Using random amplified polymorphic DNA for evaluating genetic relationships among papaya cultivars. Theor. Appl. Genet., 85, 697-701.

VEDEL, F. AND DELSENY, M. 1987. Repetitivity and variability of higher plant genomes. Pl. Physiol. Biochem., 25, 191-210.

WILDE, J., WAUGH, R. AND POWELL, w. 1992. Genetic fingerprinting of Theobroma clones using randomly amplified polymorphic DNA markers. Theor. Appl. Genet., 83, 871-877.

WILLIAMS, J. G. K., KUBELIK, A. R., LIVAK, K. J., RAFALSKI, J. A. AND TINGEY, s. v. 1990. DNA polymorphisms amplified by arbitrary primers are useful as genetic markers. $\mathrm{Nucl}$. Acids Res., 18, 6531-6535. 